\title{
IN SEARCH OF TRUE FRIENDSHIP
}

\author{
Luciana Karine de Souza ${ }^{2}$ \\ lucianak@fafich.ufmg.br
}

\begin{abstract}
The present text proposes a discussion on the concept of true friendship. The argument is grounded mostly on Aristotle's Nicomachean Ethics, Owen Flanagan's ethics as human ecology, and on contemporary authors'works about the Greek philosopher's concept of friendship. Given that human beings flourish through 1) exercising capacities, 2) being moral, and 3) having true friendships, difficulties to establish the level of trust required by true friendships turns the search itself (for them) morally valid.
\end{abstract}

Keywords Ethics; Flourishing; Friendship.

RESUMO O presente texto propõe uma discussão sobre o conceito de amizade verdadeira. A argumentação que fundamenta o trabalho baseia-se em grande parte na Ética a Nicômaco de Aristóteles, na ética como ecologia humana de Owen Flanagan, e em autores contemporâneos sobre o conceito de amizade do filósofo grego. Considerando-se que seres humanos encontram a felicidade mediante 1) o exercicio de suas capacidades, 2) ser um ente moral, e 3) ter amizades verdadeiras, as dificuldades no estabelecimento do nível de amizade requerido nas amizades verdadeiras torna a busca (por elas), por si só, algo moralmente válido.

Palavras-chave: Ética; Felicidade; Amizade.

1 I would like to thank Prof. Owen Flanagan for advising me as a visiting scholar at Duke University, North Carolina (Fall, 2003). This paper was written during the aforementioned visit, with the financial support of CAPES/PDEE (Estágio de Doutorado no Exterior), which was part of my doctoral studies, funded by CNPq, conducted at the Graduate Program of Developmental Psychology, Federal University of Rio Grande do Sul.

2 Associate professor of the Psychology Department at Federal University of Minas Gerais. Artigo recebido em fevereiro de 2007 e aprovado em março de 2008. 
The present text proposes a discussion on the concept of true friendship. The argument is grounded mostly on Aristotle's Nicomachean Ethics, Owen Flanagan's ethics as human ecology, and on contemporary authors' works about the Greek philosopher's concept of friendship. Given that human beings flourish through 1) exercising capacities, 2) being moral, and 3) having true friendships, difficulties to find this latter type of relationship turns the search for it into an interesting, and relevant, quest.

According to Flanagan, ethics is "systematic inquiry into the conditions (of the world, of individual persons, and of groups of persons) that allow humans to flourish". ${ }^{3}$ This definition of ethics is based on an analogy with ecology. Ecology attempts to describe, explain, and predict the behavior of organisms, species, etc. It is normative science in so far as it concerns itself with flourishing - of individuals, species, whole ecosystems. Thus, knowing which environments are better for beavers to flourish (for instance), one can determine the necessary steps to create a good habitat for these animals. It is in this sense that Flanagan conceives ethics as human ecology - the study of the necessary conditions for human beings to flourish.

However, from the definition of ethics as human ecology one question arises: how to define flourishing (happiness) to humans without referring to specific social environments, or habitats. Facing the challenge of avoiding relativism in ethics, which would turn impossible any general consideration about the conditions that lead to flourish in the human case as a whole, Flanagan discusses the problem of the definition of flourishing, the problem of relativism, and the problem of repugnance. The problem of repugnance involves the acceptance, based on relativism, of ways of living and being that are considered suited to some social environments, but not to others - using the author's words, life styles that are "unmistakably bad". ${ }^{4}$

Flanagan calls the attention to the fact that in the history of humanity there have always been different conceptions of a good and meaningful life. And beyond this diversity, in each different human habitat, there has always been tension between the conditions of a meaningful and of a moral life; in other words, one cannot escape that conflict. Flourishing requires dealing with trade-offs and commitments among goods that are not mutually satisfiable. According to the author, a more realistic position toward this constant conflict between a moral life and a meaningful life will lie on admitting the search aiming at reducing the conflict. 
The problem of a definition of flourishing that could account for all humans persists. Nevertheless, it is possible to identify a considerably stable list over time and across cultures of what is morally good (friendship, love, compassion, as well as virtues like courage and honesty, for example) or bad (physical pain and suffering, murder, rape, robbery, hypocrisy, and cruelty). As for the meaningful aspect of a happy life, even though it involves a diversity of ways of making life meaningful, "across cultures one finds that being moral, that is, being a good person, is considered a necessary condition of living a meaningful life". ${ }^{5}$ In fact, Flanagan states that it is "the only absolutely necessary condition". ${ }^{6}$ Nonetheless, there is another necessary component to render a life meaningful. That is true friendship, which will be discussed further ahead.

In determining the conditions that lead to a good life, beyond living morally and having true friendships, Flanagan adds the Aristotelian principle invoked by John Rawls on his discussion of life plans and human flourishing. It is the enjoyment of being able to exercise our capacities (innate and trained abilities); enjoyment that increases as the capacities are realized or become more complex. Thus, in sum, "assuming a life is moral and that it partakes of the great good of friendship, then its meaning is filled out as an individual is able to express and realize her talents and interests".?

The true friendship addressed by Flanaganin his definition of flourishing is based on Aristotle's classification of friendships as three different types, or three different functions of friendship: friendships of utility (for example, having lunch with a colleague every Monday to discuss research topics in common), friendships of pleasure (people get along for the enjoyable end of singing), both types considered incomplete sorts of friendship, as friendship ends when the profit ends (when the research is done or when the choir is dissolved); and, finally, complete friendship (when one appreciates the other as for who he is, and not for any profit that could come out of the friendship). ${ }^{8}$

To a better discussion on friendship according to Aristotle, one needs to mention some of his considerations about the idea of happiness, or flourishing, as the supreme good. The Good is the objective, the purpose, the aim at which something or someone moves. According to the Greek philosopher: "Every craft and every investigation, and likewise every action and decision, seems 
to aim at some good; hence the good has been well described as that at which everything aims". ${ }^{9}$

To call something good is to consider that this objective is, under certain conditions, sought, ${ }^{10}$ and this end can be sometimes an activity, or a product of this activity, but in this case the outcome is considered better than the action itself. One might also consider cases in which the activity and the product are combined (for example, when a musician performs). Nevertheless, goods vary; as people, when in sickness, desire health to be happy, and when in poverty, seek money. But there is a good, beyond any specific good; something good in itself, something that is also the cause of all the other goods to be goods - the supreme good, or flourishing.

It is for the sake of happiness, the end toward which everything and everyone move, that people engage in activity to pursue their goods. "And so, if there is some end of everything that is pursued in action, this will be the good pursued in action". ${ }^{11}$ Happiness is chosen for itself because it is selfsufficient, i.e., it lacks nothing, and the self-sufficient person is happy because her happiness depends on herself, not on external conditions. ${ }^{12}$ Also, while one can pursue pleasure or wealth to achieve happiness, one cannot pursue happiness in order to be rich or healthy.

Flourishing is best understood when the function of human being is clarified. The diversity of human functions (for example, to play the piano, to build houses, to make bread) could not account for what is specially unique about humanity as a whole. Thus, "the human function is the soul's activity that expresses reason or requires reason", ${ }^{13}$ because it is rationality that makes human beings unique compared to other species. Although the expression of reason cannot be linked to a specific function, it can be related to the excellence of the activity, i.e., how fine and well the action is performed. The function of an excellent pianist is to play well, of a builder to construct good houses, of a baker to make good bread. As MacIntyre articulates, "in man's exercise of his rational powers therefore the specific human activity consists, and in the right and able exercise of them lies the specific human excellence", ${ }^{14}$ or virtue. In this sense,

9 Idem, p. 1, i1.

10 MACINTYRE. A short history of ethics: A history of moral philosophy from the Homeric age to the twentieth century, 1998.

11 ARISTOTLE, p. 13, i7.

12 IRWIN, Glossary. In: ARISTOTLE. Nicomachean Ethics, 1985.

13 ARISTOTLE, p. 17 , i7.

14 MACINTYRE, p. 62. 
happy is a predicate to be used of a whole life. It is lives that we are judging when we call someone happy or unhappy and not particular states or actions. The individual actions and projects which make up a life are judged as virtuous or not, and the whole as happy or unhappy. ${ }^{15}$

As already mentioned, happiness for Aristotle is the exercise of virtues as well as to where they naturally move. The good man has pleasure in exercising virtuous activities, and so he is happy because he lives well and does well in his actions. That is why happiness is a general virtue or involves the expression of specific virtues; and also why pleasure does not have to be added to the life of the happy person.

Aristotle classified virtues in two ways of displaying rationality. Through the exercise of intellectual virtues (like wisdom and intelligence) we express rationality at best in itself; and also at best through activities that obey the precepts of reason (where one can succeed or fail) - the moral virtues (like generosity, bravery, and temperance). Intellectual virtues mostly depend on explicit instruction; moral virtues, on habit. Thus, virtues depend on training, since a person becomes honest by acting honestly; and on continuity, as a single act of honesty does not make a person honest. Reason also provides the virtuous person with the ability to choose correctly among pleasures and pains, and this opportunity of choice indicates that virtuous actions are voluntary (as opposed to non-voluntary actions, based on compulsion or ignorance). Nevertheless, as MacIntyre highlights, Aristotle does not assert that we always act rationally, "but that the standards by which men judge their own actions are those of reason". ${ }^{16}$ It implies that the chosen behavior has an implicit purpose that identifies the actor as human, who knows what he is doing, and in whose behavior one can identify some principle of action. Virtues are displayed by actions that lead us to display those kind of actions. Thus the honesty that I identify when someone is acting honestly with me - i.e., perception ruled by reason - makes me act honestly, also in accord with judgment by reason (i.e., I act according its evaluation).

Understanding the Aristotelian concept of flourishing prepares the field for the search for true friendship. But before getting to the aforementioned quest, it is relevant to offer an overview of Aristotle's ideas on friendship based on virtue. 


\section{Friendship in Aristotle}

Aristotle defines friendship as "a virtue, or involves virtue, and besides is most necessary for our life. For no one would choose to live without friends even if he had all the other goods". ${ }^{17}$ As for true friendship, he considers it as the greatest of external goods, which also include "wealth, political power, noble birth, good children, and specially honor" (as apart from goods of the soul and goods of the body). ${ }^{18}$ It requires mutual loving, or reciprocity, in the sense that both friends must desire goods for each other's sake, and not for their own personal sake. In this perfect friendship one also finds the functions of utility and pleasure, but to a lesser extent, for they are not enough to qualify a true friendship. According to Aristotle,

Complete friendship is the friendship of good people similar in virtue; for they wish goods in the same way to each other in so far as they are good, and they are good in themselves. Now those who wish goods to their friend for the friend's own sake are friends most of all; for they have this attitude because of the friend himself, not coincidentally. Hence these people's friendship lasts as long as they are good; and virtue is enduring. ${ }^{19}$

This sort of friendship lasts longer, because of similarity in virtues and unconditional love for the other person. At the same time, that is why these relationships tend to be rare, for rare are good people. Moreover, these friendships demand time, since, as the philosopher wisely alerts, "though the wish for friendship comes quickly, friendship does not". ${ }^{20}$

Since the good person is only virtuous through the exercising of virtues, which make flourishing possible, interaction with other people is necessary for the person to benefit from her own qualities, like honesty, for example. Assuming that human beings are by nature social beings, it is not possible to flourish in solitude. Likewise, the virtuous person finds happiness in the presence of her friends, who are friends because they have the same virtues. For Aristotle is referring to the unity of virtues, i.e., the good person has a complete set of virtues necessary for flourishing; so, if you have one, you have them all. It would be interesting to dedicate some lines to discuss the idea of a person possessing all virtues, and therefore the idea of the true friend as a mirror of the other's virtues. 


\section{Flourishing, friendship, and virtue}

According to Flanagan, ${ }^{21}$ there are many good character traits available, and new social situations require, or even help, to develop new ones. As an example, Blum ${ }^{22}$ recently discussed the necessity, brought up by "new-old" social experiences, of analysing the virtues referred to by him as welcoming of blackness, civic racial egalitarianism and seeing other as individuals. MacIntyre also highlights the intrinsic relationship between moral trends and the changing characteristics of societies throughout history. As Flanagan exemplifies, charity did not belong to Aristotle's list of moral virtues, and friendship did not seem to be included in the concept of Christian charity. In fact, this relativity of the obligatory good traits of character shows that "there is no single ideal of moral personality suited for all times and places, and thus an ethics of virtue is no more capable than an ethics of principle of delivering an uncontroversial portrait of the morally excellent person". ${ }^{23}$

A current list of all the character traits would include a lot of virtues, different ones, even virtues with opposite nature (like serenity and vivaciousness). In accord with Flanagan, the idea of a person possessing all the known and possible virtues is a fantastic picture - real human beings cannot correspond to this demand. "A better idea is that the fully virtuous person possesses some small set of virtues that are considered absolutely essential, and also possesses some other good qualities from the set of non-mandatory virtues". ${ }^{24}$ This proposal is more open for real persons to try to fit the ideal. Finally, if one considers that a moral person does not have all possible virtues, the situation will be the same for her friend. Thus true friends share some virtues, but taken together they can also have complementary virtues. In fact, there are friendships in which the individuals involved admire opposite virtues in one another. ${ }^{25}$

Flourishing arises through the activity that is performed and actualized. The activity of the good person is excellent and pleasant in itself, because "what is our own is pleasant", ${ }^{26}$ hence why the virtuous person does not need pleasure (in addition). But it is necessary to have virtuous friends because the good person is more able of observing others and their activities than herself

21 FLANAGAN. Varieties of moral personality: Ethics and psychological realism, 1991.

22 BLUM, Lawrence. Virtue and race. Seminar presented at the Philosophy Department, Duke University, North Carolina, 2003.

23 MACINTYRE, 1998, p. 11.

24 FLANAGAN, 1991, p. 10.

25 FLANAGAN, verbal information, 2004.

26 ARISTOTLE, p. 258 , ix9. 
and her own actions; she finds pleasure in the actions of her virtuous friends; and the good person decides to observe, in her virtuous friend, the virtuous actions that are familiar to her in the sense that they also constitute the person that she is.

\section{True friendship}

Both good people and bad people (vicious people) can have friendships of utility and pleasure, but only good people can find true or complete friendship, for amongst them there is trust, the belief that they would never do injustice to a friend. Indeed, there is a passage frequently quoted about this relation between friendship and justice: "If people are friends, they have no need of justice, but if they are just they need friendship in addition; and the justice that is most just seems to belong to friendship". ${ }^{27}$ In a discussion about friendship and justice in Aristotle, Sokolowski asserts that friendship is above justice, for "friendship (...) crowns all the moral virtues, including justice; it surpasses justice and brings it to perfection". ${ }^{28}$ Moreover, "friendships are exclusive in a way that justice is not. We can be just toward everyone, but we cannot be friends with everyone". ${ }^{29}$

Friendships might come pretty naturally or effortlessly, depending on situations, on different personalities. Nevertheless, for Aristotle, true friendships require experience with the friend and getting accustomed to him, which are difficult tasks. That is also why these kinds of friendships are few. Moreover, "those who have many friends and treat everyone as close to them seem to be friends to no one, except in a fellow-citizen's way". ${ }^{30}$ Complete friendships require that the friends live together, i.e., they have things in common, they like the same things. The person perceives herself to be good and thus deserving to be loved. She also perceives her friend good and lovable (choiceworthy), and she wishes the same good for her friend, for, "in friendship, the well-being of each is the well-being of both". ${ }^{31}$ These perceptions are only active if they interact, because virtue comes from action. As Sokolowski puts it, "to be able to engage in true human friendship is the highest moral condition". 32 
The characterization of a true friend as an external good may not give the idea that the friend is only another self in the sense of a separate being, but that he is also another self in the sense that we share goodness, and share it in activity. As Pangle puts it,

a true friend, if he is another self, would seem not to be simply external to yourself but, in a deep sense, intertwined with one's own soul; a true friend is far more secure than goods that depend chiefly on fortune or public opinion; and most importantly, having a friend means at bottom not having a possession but engaging in an activity of the soul..$^{33}$

However, if the good man has the capacity of being a true friend, i.e., this is an inherent feature of him, the detection of another person that matches his soul as another self may depend on good fortune.

In this direction, Flanagan highlights the distinction between the person that does not seek true friendships and the person that pursues that kind of relationship but does not find it. The former must be losing an essential component of a meaningful life. In the latter case, one needs to understand that the world does not always contribute to our aspirations. Thus, even so one can not find true friendships, the search for them must consist in one of the necessary conditions of a good life.

It is worth presenting Schollmeier's defense of perfect friendships as essentially altruistic relationships. ${ }^{34}$ Along with Jacquette, ${ }^{35}$ Schollmeier considers Aristotle's theory of friendship as an integral part of his ethical and political theories. Good friendships are essentially altruistic because they involve "good will and good wishes, reciprocated and recognized, for the sake of the happiness of another person", ${ }^{36}$ and they are only accidentally pleasant or useful for ourselves. And there is no paradox in saying that we find happiness through the happiness of our true friend, i.e., "the happiness of another is a good belonging to us", ${ }^{37}$ for now the friendship may sound egocentric. It is, in fact, altruistic when we realize that

another self is an actualization of Aristotle's moral principle in the character and activity of another person. That is to say, it is an actualization of happiness and virtue in another person. Another self is therefore a good, for someone who is happy has

33 PANGLE, p. 184.

34 SCHOLLMEIER. Other selves: Aristotle on personal and political friendship, 1994.

35 JACQUETTE. Aristotle on the value of friendship as a motivation for morality, 2001.

36 SCHOLLMEIER, 1994, p. 2.

37 Idem, p. 3. 
human goodness; and another self belongs to us, for we make other selves ours by helping them attain or retain their happiness. They become our work, so to speak. ${ }^{38}$

Aristotle's true friendship is possible only between good, virtuous men, alike in virtue, which excludes women, slaves, and also friendships among unequals in status, i.e., a superior person and an inferior person (father and son, man and woman, master and slave). Another contemporary feature that Flanagan links to true friendship is the fact that, although it requires similarity of interests, values, and intelligence, these relationships might occur with anyone: between men and women, parents and their children, and as aforementioned, between people with different but complementary character traits.

The truly happy person does not need friendships of utility, for she seeks moderation in material goods, and does not need too many friends of pleasure, for she already feels life is full and does not require more to light it up. Pangle criticizes this view as one looks at it with contemporary aspirations. The happy person would never feel the need we do to experience a lot of things that distract us from our work and problems, little amusements that we value in everyday life. Nevertheless, as Pangle puts it, despite the self-sufficiency of the happy person, Aristotle "leaves open a window for friendship to enter such a life", ${ }^{39}$ because the pleasures that the person finds can only be enhanced through the company of a friend, a true friend, of course. With respect to Pangle's view, Aristotle does not seem to mean that the good person does not need the little amusements that the author fears loosing - enjoyable and or useful outcomes brought up by "lower friendships", but that the virtuous person does not need too many of these instead.

Jacquette proposes an interesting analysis about Aristotle's writings on friendship (books 8 and 9, Nicomachean Ethics). For Nicomachean Ethics seems a compilation of lectures, notes, or fragments of an essay that Aristotle did not intend to publish, the writings on friendship could be seen as apart from the other discussions (e.g., the discussion on justice). However, Jacquette argues for more attention to the role of friendship in the search for the answer of "why be moral?" and happiness pursuit, because books 8 and 9 are more important and are intimately linked to the rest of the work. More specifically, Jacquette tries to show how true friendship is a source of motivation to morality. 
Jacquette points out that in several passages Aristotle explicitly mentions that friendship conduces to correct moral action, for it involves opportunity for exercising virtues. Friends help each other to be virtuous, and by doing so, they also help each other in realizing - through activity - each other's potential in the search for happiness. In addition, only virtuous persons can have true friendships, because they wish the good to each other for the friend's sake, not for any advantage or pleasure that could be gained from the relationship. In contrast, morally bad persons can only be friends if the friendship aims at obtaining pleasure or utility. In true friendships, virtuous persons choose only persons who are also virtuous, because virtuous friends encourage each other in the cultivation of virtue, perfection, or excellence of character. This is the basis and purpose of perfect friendships. The motivation that arises from this relationship works to overcome weakness of will, i.e., when the individual knows the right action but lacks adequate motivation due to frustration, fatigue, or conflicting interests. According to Jacquette, true friends help each other to achieve a morally good life in the search for happiness

by offering mutual assistance in achieving virtue, including mastering the will, setting positive examples for one another, instilling a sense of shame for real or imagined wrongdoing, and in these and other ways enabling each other to produce morally worthy actions. ${ }^{40}$

In conclusion, the author highlights that, in order to be worthy of perfect friendship, the natural human need and desire for social relationships motivate morally good actions: "For Aristotle, to be worthy of the highest type of friendship is intrinsically valuable in and of itself, because it is in this way that we achieve our greatest natural human potential as social animals". ${ }^{41}$

From Jacquette's analysis one can more explicitly identify functions of the true friend (beyond being only enjoyable and providing instrumental help), like encouraging, supporting, setting good (positive) examples, and preventing the friend from doing wrong (by shaming, persuading, or physically preventing), helping in overcoming weakness of will and reaching moral excellence in the search for happiness. In this sense, when Flanagan mentions that flourishing requires dealing with a constant tension between a moral and a meaningful life, and that a realist position involves reducing the conflit, one could add, along with Jacquette's lines, that the true friend helps his friends in 
diminishing that tension. Indeed, on his discussion about meaningful human lives at different degrees, Flanagan seems to keep friendship and morality together. The author states that "being moral, having true friends, and having opportunities to express our talents, to find meaningful work, to create and live among beautiful things, and to live cooperatively in social environments where we trust each other" are required for a meaningful life, that having only some of these requirements leads to a less meaningful existence, but lacking "all of these things, especially the first two, then our life is meaningless". ${ }^{42}$

Bukowski and Sippola ${ }^{43}$ state that Aristotle's true friendship requires the recognition of goodness in the other person, a greater appreciation or understanding of the other person for what she is. These special friendships also require the exercise of virtues like kindness, justice, and benevolence. Friendships of utility and of pleasure are sought for the benefits or enjoyment they offer, and so are described as self-centered friendships. They depend on specific events or circumstances, and cease when the ephemeral ends are no more present for changes in circumstances. On the other hand, as goodness and virtue are not linked to specific contexts, they maximize the longevity and intensity of friendships of the best sort, keeping them consistent through time and situations. In true friendship, it is necessary to recognize the virtues of the friend, and have them recognized by him, on us, as well. Acting with generosity, honesty, kindness, and loyalty towards your true friend is doing well to him, ${ }^{44}$ and the activity shifts its focus from oneself to the other person. Nevertheless, the action must come with pleasure, i.e., generosity is only truly present when on acting in conformity with this virtue the person feels joy. In the same way, one has a true friendship for the pleasure that comes from itself, for the friend is loved by who he is in the first place, not by any kind of tradeoff that could come from the friendship. That is why friendships of pleasure are closer to true friendships than friendships of utility.

\section{Final words}

Looking at Aristotle's ideas of a happy person and of true friendships with a contemporary view, it is not difficult to question such ideals. As mentioned earlier, given the different social environments that can be found today, and the increasing interaction among them, both in great contrast with Aristotle's 
small and stable world of the Greek polis, his definition of flourishing needs revision, but need not to be discarded. Awareness of the diverse ways of flourishing according to distinct human habitats, as well as of the different ways that happiness has been defined throughout the centuries, stimulates the search for the necessary conditions for flourishing. As indicated by Flanagan, although being moral may be the only absolutely necessary condition of a meaningful and good life for human beings, the opportunity to exercise one's talents and interests, and the search for true friendships are also pointed out among the conditions for us to flourish.

One can also question Aristotle's idea of true friendships with contemporary eyes. As an ideal for people to pursue, these relationships seem to be an important feature for a happy life. But do people seek for this kind of relationship? Are these special friendships considered more important than regular ones? How do people define true friendships in contemporary societies? Given that contemporary life is filled with competition, rivalry, and loneliness, it is worth trying to look for answers to those questions. The search for the true friendship of today's interactions might then be a necessary, and meaningful, quest.

\section{References}

ARISTOTLE. Nicomachean ethics. Translated by T. Irwin. Indianapolis: Hackett Publishing Company, 1985.

BUKOWSKI, William; SIPPOLA, Lorrie. Friendship and morality: (How) are they related? In: BUKOWSKI, W.; NEWCOMB; A.; Hartup, W. The company they keep: Friendship in childhood and adolescence. Cambridge, U.K.: Cambridge University Press, 1996. p. 238-261.

FLANAGAN, Owen. The problem of the soul: Two visions of mind and how to reconcile them. New York: Basic Books, 2002.

FLANAGAN, Owen. Varieties of moral personality: Ethics and psychological realism. Cambridge, Mass.; London, UK: Harvard University Press, 1991.

IRWIN, Terence. Glossary. In: ARISTOTLE. Nicomachean ethics. Translated by T. Irwin. Indianapolis: Hackett Publishing Company, 1985. p. 385-432.

JACQUETTE, Dale. Aristotle on the value of friendship as a motivation for morality. The Journal of Value Inquiry, n. 35, p. 371-389, 2001.

MACINTYRE, Alasdair. A short history of ethics: A history of moral philosophy from the Homeric age to the twentieth century. $2^{\text {nd }}$ ed. Notre Dame, Indiana: University of Notre Dame Press, 1998.

PANGLE, Lorraine. Aristotle and the philosophy of friendship. Cambridge, U.K.: Cambridge University Press, 2003. 
SCHOLLMEIER, Paul. Other selves: Aristotle on personal and political friendship. Albany, N.Y.: State University of New York Press, 1994.

SOKOLOWSKI, Robert. Friendship and moral action in Aristotle. The Journal of Value Inquiry, n. 35, p. 355-369, 2001. 